\author{
Aleksander Bobko \\ ORCID: https://orcid.org/0000-0003-0609-6982 \\ University of Rzeszów, Poland
}

\title{
21 Gdańsk Demands - a Political Monument
}

\begin{abstract}
In the history of European civilisation there have been several documents of particular cultural weight and symbolic meaning. From Magna Carta Libertatum of 1215 to the Universal Declaration of Human Rights from 1948 we can trace the development of political ideas which, while being rooted in religious and philosophical thought, have had a strong impact on the lives of whole societies. In this article I attempt to look at the famous 21 Gdańsk demands from that perspective. The document, signed in August 1980 kindled a peace process which culminated in the collapse of communism in Europe. I would like to infer a relation between the possibility of signing such a document and the election of Karol Wojtyła as Pope. It also seemed interesting to compare the content of the 21 Gdańsk Agreement with that of the less well-known Rzeszów-Ustrzyki Dolne Protocol signed several months later.
\end{abstract}

\section{Keywords}

Gdańsk Agreement 1980, Monuments to ideas, Human rights, John Paul II.

Monuments occupy a special place in the history of civilization. Notable examples are the pyramids of Egypt, gothic cathedrals, the Statue of Liberty and the Eiffel Tower - all of them, while revealing the spirit of the times in which they were built, carry inspiring messages for subsequent generations. Besides these material representations of cultural and historical values, there exist at least several documents of particular importance and symbolic meaning. The Decalogue, 
Magna Carta and The Universal Declaration of Human Rights illustrate the way ethical, social and political ideas have been developing. Anchored in religious and philosophical traditions, these "monuments to ideas" have transformed, and still do, the lives of whole societies. Although they were placed in a local context, their message is universal.

In this article I attempt to look at the famous 21 Gdańsk Demands and the idea of solidarity from this perspective. The document, signed in August 1980, launched the peace process which led to the collapse of communism in Europe. It was an expression of the permanent dissent of Polish society against the totalitarian system imposed after World War II. Many factors contributed to the signing of the demands, but one was of particular significance - the election of Karol Wojtyła as Pope John Paul II.

The very fact of electing a Pole to the Papacy, then his teaching, especially the words uttered during his first visit to Poland in 1979, enhanced a feeling of togetherness among Polish people. It was as if in response to the Pope's call, the Holy Spirit descended indeed and renewed our Polish land. Solidarity was the embodiment of this spiritual revival. And the Pope spoke about it both eloquently and simply, for example, in one of his homilies he said that the inspiration for interpersonal and communal solidarity should be the Apostle's words in his Letter to the Galatians: „Bear one another's burdens and so fulfil the law of Christ." It was an extraordinary phenomenon that such apparently abstract invocations, full of pathos, had a powerful appeal for Polish society and impacted so positively on ethical relations. A new space for trust, mutual concern and attention was born - the strike in the Gdańsk Shipyard was triggered by the dock workers who protested against the dismissal of Anna Walentynowicz who was one of them. Then, in a sense of solidarity, the strike spread to other industrial centres.

It is difficult to say what those protests would have looked like without the ethos which emerged after the election of Karol Wojtyła as Pope. Undoubtedly, however, the Gdańsk Agreement was a consequence of what Pope John Paul II inculcated in Polish people during his pontificate. At that time, the very fact that a Pole was leading the See of Peter, his teachings concerning both religious and ethical matters as well as those addressing the political sphere of human rights, were of utmost importance for the people of Poland.

${ }^{1}$ John Paul II, Gdańsk homily, 12.06.1987, «L’Osservatore Romano » (1987), p. 8. 
Today, from a 40 year perspective, the question about the significance of the 21 Gdańsk Demands is worth asking. Was their adoption just a „local episode” or do they have a far more universal meaning. In other words, are they part of the great political monuments? To answer this it is interesting to compare the Gdańsk Agreement from August 1980 to the less well-known Rzeszów-Ustrzyki Dolne Agreement from February 1981.

\section{Monuments to ideas}

We should start this short review of the documents deserving to be called "monuments to ideas" with the Decalogue. The ten verses inscribed on the two stone tablets, which can be contained on a single sheet of paper, have served for a large part of humanity, regardless of religious beliefs, as a moral foundation and constant point of reference. On the one hand, they express man's commitment towards the Absolute, indicating that human existence reaches beyond this world and that man was created for things grand and everlasting. Conversely, based on a consistent system of moral precepts and injunctions, they improve human relationships, underlying the importance of obligations that we have towards our neighbours.

Another document of considerable significance was the Magna Carta Libertatum, signed by King John of England in 1215. Although most of its clauses referred to the specific problems of the time, some of them may be regarded, from a modern perspective, as essential and groundbreaking for the rule of law and human rights. This is reflected in clause 39: „No free man shall be seized or imprisoned, or stripped of his rights or possesions, or outlawed or exiled, or deprived of his standing in any other way, nor will be proceed with force agains him, or send others to do so, except by the lawful judgement of his equels or by the law of the land"2. Thus, the charter acknowledged the inalienable rights of individuals and placed limits on the royal (executive) power which subsequently led to the evolution of parliament and legal systems protecting the rights of every citizen.

The idea of tolerance, of such importance to modern man, has been shaped in the context of conflict over freedom of conscience, especially at the time of the

2 The Western Tradition, vol. I, From the Ancient World to Louis XIV, Ed. E. Weber, Boston 1965, p. 218. 
Enlightenment. John Locke's Letter on Tolerance from 1690 is a breakthrough document in this respect. It was, however, Paweł Włodkowic, a distingushed Polish scholar, Rector of the Jagiellonian University, who was the true forerunner of religious freedom. At the 1414 Council of Constance he declared that peaceful infidels, as well as their properties, should not be disturbed and that they could legitimately have states and could be their rulers as these things were created not only for Christians, but for all sentient beings ${ }^{3}$. Such a statement, obvious to us, was, however, quite unusual at the time of Włodkowic. So his work also belongs to the „ideological monuments" which have had a great impact on shaping the European social order.

The next historic document was the United States Declaration of Independence from 1776. It says: „We hold these truths to be self-evident that all men are created equal, are endowed by their Creator with certain unalienable Rights, that among these are Life, Liberty and pursuit of Happiness." ${ }^{34}$ We find here the tenets of contemporary thought and political practice - people are equal, their lives and freedom are of highest value which should be protected by government without too much interference in their affairs, as everybody has the right to pursue happiness in their own way. It is difficult to overestimate the influence of the principles formulated in the Declaration on legal texts from the 19th and 2oth centuries.

And finally the Universal Declaration of Human Rights adopted by the United Nations General Assembly on 10 December 1948 in Paris, shortly after the tragic experiences of the Second World War. It consists of 30 articles which constitute a catalogue of basic human rights that most governments committed themselves to secure. This catalogue is a synthesis of western political thought and, for the last 70 years, has been a point of reference and a criterion which have helped to distingush from dictatorships civilised political systems which serve the development of freedom. ${ }^{5}$

${ }^{3}$ See Wielkie mowy historii, t. 1: Od Mojżesza do Napoleona, Wyd. Polityka, Warszawa 2006.

${ }^{4}$ United States Declaration of Independence.

${ }^{5}$ Here I'm not going into details of how the idea of human rights has evolved over the last few decades as expressed by other declarations, for instance by the Charter of Fundamental Rights of the European Union, adopted in Nice in 2000. 


\section{Gdańsk Agreement}

It is interesting to ask how the Gdańsk Agreement, signed in August 1980, compares with above-mentioned historic documents.

It needs to be noted that the Agreement originated in unusual and spectacular circumstances. In the heart of communist darkness an intense workers' protest broke out and was not brutally suppressed as had been the case previously but, contrarily, the government undertook negotiations which resulted in its agreeing to the workers' most important demands. It was thus that the great idea of Solidarity was born. Józef Tischner, an eminent Polish philosopher and theologian, one of the ideological leaders of the Solidarity movement, wrote: "The word solidarity comprises our anxious hopes, stimulates courage and reasoning, unites people who, just yesterday, were indifferent to one another. History invents words in order to be shaped by them. The word $<$ solidarity $>$ has joined other Polish words in changing our times." ${ }^{\prime 6}$ And indeed, the so called „Solidarity Carnival”, unheard of in a totalitarian state, lasted from August 1980 to December $1981^{7}$. The events in Poland were supported by the international community beyond the Iron Curtain. The straightforwardness of the word solidarity engendered the sincere hope that a non-violent way of resolving conflicts could prevail. The Gdańsk Agreement was a symbolic manifestation of the idea of solidarity, so becoming an ideological monument.

Listed below are the terms of the Agreement:

1. Acceptance of free trade unions independent of the Communist Party and of enterprises, in accordance with convention No. 87 of the International Labor Organization concerning the right to form free trade unions, which was ratified by the Communist Government of Poland.

2. A guarantee of the right to strike and of the security of strikers and those aiding them.

3. Compliance with the constitutional guarantee of freedom of speech, the press and publication, including freedom for independent publishers, and the availability of the mass media to representatives of all faiths.

4. A return of former rights to: 1) People dismissed from work after the 1970 and 1976 strikes, and 2) Students expelled from school because of their views. The release of all political prisoners, among them Edward Zadrozynski, Jan Kozlowski, and Marek Kozlowski. A halt in repression of the individual because of personal conviction.

${ }^{6}$ See J. Tischner, Etyka solidarności, Kraków, 1981, p. 5.

7 This unusual phenenomon ended after the imposition of martial law in 1981. 
5. Availability to the mass media of information about the formation of the Interfactory Strike Committee and publication of its demands.

6. The undertaking of actions aimed at bringing the country out of its crisis situation by the following means: a) making public complete information about the social-economic situation, and b) enabling all sectors and social classes to take part in discussion of the reform programme.

7. Compensation of all workers taking part in the strike for the period of the strike, with vacation pay from the Central Council of Trade Unions.

8 . An increase in the base pay of each worker by 2,000 złoty a month as compensation for the recent raise in prices.

9. Guaranteed automatic increases in pay on the basis of increases in prices and the decline in real income.

10. A full supply of food products for the domestic market, with exports limited to surpluses.

11. The abolition of ,commercial' prices and of other sales for hard currency in special shops.

12. The selection of management personnel on the basis of qualifications, not party membership. Privileges of the secret police, regular police and party apparatus are to be eliminated by equalizing family subsidies, abolishing special stores, etc. 13. The introduction of food coupons for meat and meat products (during the period in which control of the market situation is regained).

14. Reduction in the age for retirement for women to 50 and for men to 55, or after 30 years' employment in Poland for women and 35 years for men, regardless of age.

15. Conformity of old-age pensions and annuities with what has actually been paid in.

16. Improvements in the working conditions of the health service to insure full medical care for workers.

17. Assurances of a reasonable number of places in day-care centers and kindergartens for the children of working mothers.

18. Paid maternity leave for three years.

19. A decrease in the waiting period for apartments.

20. An increase in the commuter's allowance to 100 złoty from 40, with a supplemental benefit on separation.

21. A day of rest on Saturday. Workers in the brigade system or round-the-clock jobs are to be compensated for the loss of free Saturdays with an increased leave or other paid time off. ${ }^{8}$

${ }^{8}$ Wikipedia, see also UNESCO: Poland - Twenty-One Demands, Gdańsk, August 1980. The birth of the SOLIDARITY trade union - a massive social movement. 
The first thing we notice when trying to interpret the content of the demands is their somewhat chaotic character and lack of orderly and deliberate structure. ${ }^{9}$ The first three points are the most important: legalisation of free trade unions, the right to strike and (theoretically guaranteed by the Constitution of the Polish People's Republic) freedom of speech. Demands of this kind were considered truly revolutionary in a Soviet-bloc country, as the underlying principle of the communist regime was to eliminate all independent power in its subjects. It seems that the protestors' attention was focused on the above three demands, the remainder considered to be just an appendix. Yet the appendix is worth having a look at.

The remaining demands can be divided into three categories. First, there is a whole range of actual social and economic demands as in points $8,9,11,13$, $14,15,17,18,20,21$. Points 6, 10, 16,19 also deal with social problems but more generally. They concern, for example, the improvement in the functioning of the health service. The third category refers to current affairs, the most important being the release of political prisoners. Point 12 joins the first three in the category of political demands.

Thus, it can be seen that most of the Gdańsk demands were the claims of the new trade unions where corporate group interest predominated. Still there was no trace of reflection on how the demands could be implemented. There were no questions about financial and legal problems, deadlines, persons or institutions responsible for implementation. It was for the government to put things right and up to the trade unions to enforce the government's commitments using such pressure instruments as the right to strike. It is also notable that the document did not contain any claims which would refer to entrepreneurial freedom.

So the strength of the Gdańsk Agreement resulted from the dynamics of political events and its basic role was to undermine the tightly-knit totalitarian system. It was symbolised by the idea of solidarity as giving hope and opening up the possibility of peaceful transformations in the Soviet Bloc. Still the substantive content of the document lacks a more profound message or axiological references. Everything boils down to one, basic demand: legalising free trade unions with the right to strike.

9 Which is rather odd because although these were workers' demands, experts who were university graduates contributed to their formulation. 


\section{Rzeszów - Ustrzyki Agreement}

The less known Rzeszów-Ustrzyki Dolne Agreement adopted half a year later, in February 1981, had quite a different form. ${ }^{10}$ Although it was one of the important events that took place during the Solidarity Carnival, its origins were not as spectacular as those of the Gdańsk Agreement. After the legalisation of the workers' Solidarity, individual farmers aspired to have their own labour union. The government did not agree to it leading to a conflict lasting for several months which involved sit-in strikes first in Ustrzyki Dolne then in Rzeszów, in south-eastern Poland. The events culminated in the signing, on 19 February in Rzeszów of the Protocol to the Agreement between the Government Commission and the Strike Committee.

The content of this eight unit document is well thought out and its form is a coherent ensemble. It refers to existing legal acts, sets deadlines, identifies authorities and organisations responsible for implementing assumed liabilities. The first two units contain proposals for modifications of the laws safeguarding private farm ownership as well as creating better conditions for agricultural activities involving land market regulations, licensing of construction projects and granting credits to farmers. Units III and IV deal with social and economic claims typical of that time, similar to those of the Gdańsk Agreement. Unit $\mathrm{V}$ proposes creating efficient democratic structures which would allow genuinely free elections of local authorities. The subsequent units contain well-advised political demands referring to education, unrestricted access to religious practice and underline the importance of historical truth.

Comparison of the two documents shows the virtue of the Rzeszów-Ustrzyki Agreement where the proposal of practical solutions predominates. Its authors understand not only the legal and economic mechanisms but also the constraints resulting from the political reality of the time. They approach the problems of local communities, families, (for example, acute alcoholism at that time), based on Polish tradition and the teaching of the Church. This aspect seems to be missing from the Gdańsk demands, possibly resulting from the differences in mentality between workers employed in big, state-owned industries and farmers who, even under the communist regime, were private owners. The greater maturity of the Rzeszów-Ustrzyki Agreement might also have been the

10 The document, consisting of about 6 pages can be found in: Strajki Ustrzycko-Rzeszowskie, IPN, Rzeszów 2014, pp. 18-20. 
consequence of the pace of change of social and political events in the period between August 1980 and February 1981 and a surge in political awareness related to it. In Gdańsk the focus was on legalising free trade unions, while all the remaining claims seemed to have been subordinate.

\section{Conclusion}

To summarise, the 21 Gdańsk demands and the idea of solidarity they engender, deserve to be deemed a political monument which has had its stamp on the political reality both in Poland and Europe as a whole. The strength of this monument derives from the fact that it demonstrates the triumph of good over evil, even if only in the short term. The message „overcome evil with good” which has been proclaimed by Christianity over centuries and which was recalled with particular emphasis by John Paul II, materialised in the Gdańsk Agreement. This document is a fascinating phenomenon, born in the exceptional atmosphere of August 1980, which still remains an inspiration for people believing in the superiority of ethos over brute force.

Yet the very content of the 21 demands does not match the symbolic weight and importance of this document and the idea of solidarity. As a whole it is rather a collection of claims formulated under the pressure of specific problems of that time and randomly assembled. We can speculate that each point was the subject of long and conflict-ridden negotiations. Still, the underlying principle was to urge government authorities to give up violence and to recognise the workers' right to function within the framework of free trade unions. In this sense, the Gdańsk agreement does not contain an intellectual message which, in the future, would result in creating a just and cohesive society. ${ }^{11}$ In this respect, the Rzeszów-Ustrzyki Protocol seems to be more practical and better developed. However, it is the Gdańsk Agreement which, for obvious reasons, will claim its rightful place in the pantheon of political monuments.

11 This opinion can be validated by the fact that the idea of solidarity did not play a significant role after 1989 when real political changes became possible in Poland. 


\section{Bibliography}

John Paul II, Gdańsk homily, 12.06. 1987, «L'Osservatore Romano » (1987), p. 8.

Magna Carta Libertatum The Western Tradition, vol. I, From the Ancient World to Louis XIV, Ed. E. Weber, Boston 1965, p. 218.

Wielkie mowy historii, t. 1: Od Mojżesza do Napoleona, Wyd. Polityka, Warszawa 2006.

United States Declaration of Independence.

Universal Declaration of Human Rights.

Tischner J., Etyka solidarności, Kraków 1981.

Strajki Ustrzycko-Rzeszowskie, IPN, Rzeszów 2014. 